\title{
Isosorbide Mononitrate versus Misoprostol for Cervical Ripening in Early Missed Abortion
}

\author{
MUHAMMED I.M. LABAN, M.Sc.; MOUSTAFA Z. MOUSTAFA, M.D.; HESHAM M.E. BORG, M.D. and \\ NAGLAA A. HUSSEIN, M.D.
}

The Department of Obstetrics and Gynecology, Faculty of Medicine, Tanta University

\begin{abstract}
Background: First-trimester pregnancy loss is the most common complication of human reproduction with an incidence ranging between 50 and $70 \%$ of all conceptions. The uterine cervix has to be firm enough to retain the conceptus through the pregnancy. Cervical ripening and maturation is very important prerequisite for the successful termination of pregnancy. Misoprostol softens the cervix and cause uterine contractions used for ripening of the cervix before surgical or for medical abortion. Isosorbide mononitrate promote cervical smooth muscle relaxation has been applied clinically as cervical ripening agents. First trimester abortion is terminated by surgical evacuation of the uterus.
\end{abstract}

Conclusion: Cervical preparation is beneficial prior to surgical abortion and should be routine if gestation more than 10 weeks using one of cervical ripening agents Misoprostol or IMN.

Aim of Study: To compare efficacy and safety of Isosorbide Mononitrate (IMN) and misoprostol for cervical ripening prior to surgical termination of missed abortion aged between 8 and 12 weeks.

Patients and Methods: Eighty patients aged between 20 $\& 35$ years presenting with missed abortion in early weeks of gestation and requiring medical or surgical evacuation of the retained products of conception were included in this prospective clinical study. Number of doses required to achieve cervical ripening, Induction-Ripening interval (I/R) was recorded. Amount of operative blood loss and other safety indices were assessed.

Results: Number of doses to achieve cervical ripening using (Misoprostol) was significantly less than number of the (IMN) doses and with further analytical statistics about 66\% of cases have successful ripening using (Misoprostol) compared to only $31 \%$ using (IMN). The mean (I/R interval) was as follows; 18.5 hours for (Misoprostol) and 22.5 hours for (IMN); with much less operative blood loss for the Misoprostol group than the IMN group.

Correspondence to: Dr. Muhammed I.M. Laban, The Department of Obstetrics and Gynecology, Faculty of Medicine, Tanta University
Key Words: Abortion-Cervical ripening - MisoprostolIsosorbide MonoNitrate (IMN).

\section{Introduction}

EARLY Pregnancy Loss (EPL) is a common obstetrical problem, upsetting the patient \& carries a small risk of coagulation defect if left untreated. Surgical management is the standard treatment but if done without prior cervical ripening is associated with complications where, the uterine cervix has to be firm enough to retain the conceptus through the pregnancy and on the other hand have the ability to soften before and during labor to enable the birth of infant. Cervical ripening and maturation is very important pre-requisite for the successful termination of pregnancy.

Cervical ripening means thinning, softening and opening of the cervix. Various pharmacological $\&$ non pharmacological methods are available for cervical ripening each having its own advantages \& disadvantages. Prostaglandins, especially PGE2, have for a long time been thought of as key mediators of cervical ripening; recently, Isosorbide mononitrate, a nitric oxide donor, promote cervical smooth muscle relaxation in early pregnancy as well as term and has been applied clinically as cervical ripening agents. First trimester abortion by surgical evacuation of the uterus is a very common, effective ( $99 \%$ efficacy rate), safe procedure and can be performed approximately between 5 and 13 weeks of gestation. However, it is reported to be associated with many complications including cervical trauma, perforation of the uterus and endometritis.

For these reasons, cervical priming using prostaglandins or nitric oxide donors prior to surgical evacuation reduces operative time, blood loss \& promotes easier mechanical dilatation. 


\section{Patients and Methods}

A prospective randomized comparative clinical trial to compare the efficacy and safety of Isosorbide Mononitrate (IMN) versus misoprostol for cervical ripening in early missed abortion aged between 8-12 weeks. This prospective study included 80 pregnant patients with missed abortion in early weeks of gestation admitted to Tanta University Hospital for medical or surgical evacuation of retained products of conception from November 2017 to June 2018.

The aim of this prospective study was to compare efficacy and safety of Isosorbide Mononitrate (IMN) and misoprostol for cervical ripening in surgical termination of missed abortion aged between 8 and 12 weeks.

\section{The participants were randomized into:}

- Group (I): n=40 cases of missed abortion received misoprostol 200mcg/tab (Misotac, Sigma Pharmaceutical Industries).

- $\operatorname{Group}(I I): \mathrm{n}=40$ cases of missed abortion received Isosorbide Mononitrate 40mg/tab (Mono MAK, October Pharma S.A.E, 6 October City).

Exclusion criteria were any cervical lesion that could affect the results (fibroid, cervical incompetence ,... etc.), cardiovascular patients on nitrate drugs and/or respiratory morbidity, hemorrhagic disorders, patients on Aspirin and/or Heparin, autoimmune disease e.g. rheumatoid arthritis, SLE, women with previous cervical surgery, hypersensitivity, any outpatient management of the missed abortion prior admission, uterine anomalies or scar (previous section, hysterotomy, myomectomy).

The study was approved by Ethical Committee at Faculty of Medicine Tanta University. All patients gave oral and written informed consent prior to the examination. The patients were undergoing surgical termination by vacuum aspiration in the first trimester of pregnancy (8-12 weeks of gestation). Gestational age was estimated on the basis of menstrual history and confirmed by transvaginal ultrasound (TVS) examination. The investigator placed the specific medications per vaginam and assessed parameters for primary outcomes who was unaware of the drug used. Two tablets of Misoprostol $200 \mathrm{mcg}$ were placed per vaginally in the posterior vaginal fornix at an interval of 6 hours in patients randomized to Group-I and two tablets of Isosorbide mononitrate $40 \mathrm{mg}$ were placed vaginally in the posterior fornix at an interval of 6 hours in patients randomized to Group-II. Both the tablets were moistened with 4-5 drops of saline before placing them per vaginally. The time of placing the first dose was considered as zero hour consequently assessed cervical changes every 3 hours and induction-ripening interval is recorded; Standard Hegar's dilators (HD), procured from the same manufacturer, and TVS were used to assess cervical dilatation. The HD which could be negotiated easily without any resistance was noted at every assessment. Those patients in whom the cervical priming was sufficient to negotiate HD10 or greater were considered successful ripening and taken up for surgical evacuation of the retained products of conception.

Assessment of the uterine cervix including consistency, length, dilatation, and diameter of internal os on regular periods every 3 hours for both groups.

The drug will be considered effective when the consistency changes to be soft, the diameter of internal os admitting HD-10 easily without resistance, length of the cervix is reduced confirmed by vaginal \& ultrasound examination. Surgical evacuation of retained products of conception will be performed after cervical ripening is achieved.

Mean arterial blood pressure and pulse rate recordings were also made on admission, before each dose given and again immediately prior to surgery by the same investigator and the development of adverse symptoms was recorded for each treatment group regarding the recognized side effects of each agent by one investigator before medication was given, at each dose given and again before anesthesia was given.

For all women, the procedures were performed under general anesthesia induced with intravenous propofol (Diprivan, Zeneca Pharma, Cheshire, UK) and maintained with intermittent repeated doses as required. Cervical dilatation and consistency was confirmed by bimanual examination under general anesthetic. The procedures were performed by experienced operators who were blind to the treatment given. Suction evacuation of the uterus was performed and the total volume lost, including blood and products of conception, measured using a calibrated suction jar.

For the purposes of this study, blood loss was taken as the total volume lost, and compared between the two groups.

\section{Results}

This study was conducted on (80) cases of early missed abortion in the 1 st trimester $(<12$ weeks) 
meeting the inclusion and exclusion criteria. Five cases $(12.50 \%)$ in group (I) refused to continue the medication and three $(7.5 \%)$ cases in group (II) refused to continue the trial. Two cases (5\%) in group (II) suffered from severe headache and the drug was discontinued. Nine $(22.5 \%)$ cases in group (I) succeeded to complete medical abortion. In group (II) six patients (15\%) also succeeded medical abortion. All were excluded from the statistical analysis. The number of cases analysied in group (I) $(n=26)$ and in group (II) $(n=29)$.

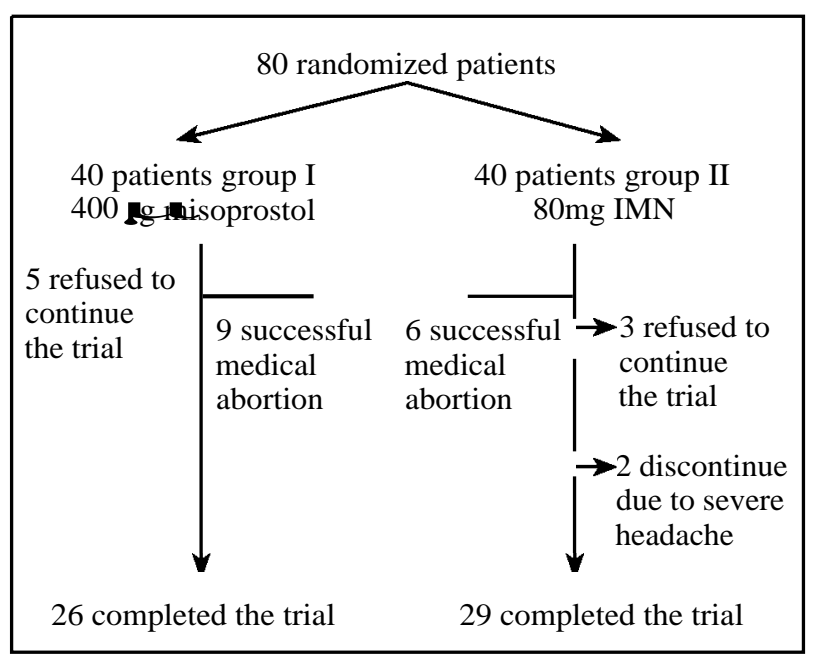

Flow chart showing the women's progress through the randomized study

IMN-isosorbide-5-mononitrate

Tables $(1,2)$ summarizes the mean arterial blood pressure and pulse rate of the two groups.

Table (1): Mean arterial blood pressure (MAP) of the two groups.

\begin{tabular}{lclc}
\hline $\begin{array}{l}\text { MAP } \\
(\mathrm{mmHg})\end{array}$ & $\begin{array}{c}\text { Misoprostol } \\
(\mathrm{n}=26)\end{array}$ & $\begin{array}{c}\text { IMN } \\
(\mathrm{n}=29)\end{array}$ & $\begin{array}{c}p \text { - } \\
\text { value }\end{array}$ \\
\hline Range & $70-100$ & $70-100$ & 0.125 \\
Mean $\pm \mathrm{SD}$ & $88 \pm 7.858$ & $85.5 \pm 10.358$ & \\
\hline
\end{tabular}

Table (2): Pulse rate of the two groups.

\begin{tabular}{llll}
\hline $\begin{array}{l}\text { Pulse rate } \\
(\mathrm{BPM})\end{array}$ & $\begin{array}{c}\text { Misoprostol } \\
(\mathrm{n}=26)\end{array}$ & $\begin{array}{c}\mathrm{IMN} \\
(\mathrm{n}=29)\end{array}$ & $\begin{array}{c}p \text { - } \\
\text { value }\end{array}$ \\
\hline Range & $70-90$ & $70-100$ & 0.133 \\
Mean \pm SD & $80.53 \pm 5.537$ & $84.92 \pm 8.206$ & \\
\hline
\end{tabular}

There were no significant correlations comparing the MAP and pulse rate of the two groups.

Tables $(3,4)$ summarize the comparison of the efficacy between the two study groups.
Table (3): Number of doses of the two study groups.

\begin{tabular}{llll}
\hline No. of doses & $\begin{array}{c}\text { Misoprostol } \\
(\mathrm{n}=26)\end{array}$ & $\begin{array}{c}\text { IMN } \\
(\mathrm{n}=29)\end{array}$ & $\begin{array}{c}p \text { - } \\
\text { value }\end{array}$ \\
\hline Range & $1-6$ & $2-7$ & 0.14 \\
Mean \pm SD & $3.7 \pm 1.78001$ & $4.5 \pm 1.5727$ & \\
\hline
\end{tabular}

Table (4): Assessment of cervical ripening.

\begin{tabular}{|c|c|c|c|}
\hline \multirow{2}{*}{$\begin{array}{l}\text { Dose } \\
\text { given }\end{array}$} & \multicolumn{2}{|c|}{ No. of cases with successful ripening } & \multirow{2}{*}{$\begin{array}{c}p- \\
\text { value }\end{array}$} \\
\hline & $\begin{array}{c}\text { Group (I) }(\%) \\
(\mathrm{n}=26)\end{array}$ & $\begin{array}{c}\text { Group (II) }(\%) \\
(\mathrm{n}=29)\end{array}$ & \\
\hline 1 st & $2(8 \%)$ & $1(3 \%)$ & 0.4226 \\
\hline 2nd & $3 \quad(12 \%)$ & $2(7 \%)$ & 0.3739 \\
\hline $3 \mathrm{rd}$ & $12(46 \%)$ & $6 \quad(21 \%)$ & $0.0031 *$ \\
\hline 4th & $7(27 \%)$ & $5 \quad(17 \%)$ & 0.1472 \\
\hline 5 th & $1(4 \%)$ & $11(38 \%)$ & NS \\
\hline 6th & $1 \quad(4 \%)$ & $2(7 \%)$ & NS \\
\hline 7th & 0 & $2(7 \%)$ & NS \\
\hline
\end{tabular}

Comparing the ripening effect of both groups after each dose given it was found that after the 1 st and 2 nd doses of the misoprostol group the number of cases with successful ripening was $8 \%$ $\& 12 \%$ respectively and in the IMN group for the same doses the results were $3 \%$ \& $7 \%$ respectively; while the peak effect of the misoprostol group between the $3 \mathrm{rd}$ and 4 th doses was $46 \%$ and $27 \%$ respectively, in the IMN group the peak between the 4 th and 5 th doses was $17 \%$ and $38 \%$ respectively.

The significant difference between the two groups was on comparing the results of $3 \mathrm{rd}$ dose of the two groups ( $p$-value $<0.05)$.

Tables $(5,6)$ summarize the comparison of the adverse effects and safety between the two study groups.

Table (5): Amount of blood loss of the two study groups.

\begin{tabular}{llll}
\hline $\begin{array}{l}\text { Amount of } \\
\text { blood loss }(\mathrm{ml})\end{array}$ & $\begin{array}{c}\text { Misoprostol } \\
(\mathrm{n}=26)\end{array}$ & $\begin{array}{c}\text { IMN } \\
(\mathrm{n}=29)\end{array}$ & $\begin{array}{c}p \text { - } \\
\text { value }\end{array}$ \\
\hline Range & $100-250$ & $150-350$ & 0.0004 \\
Mean \pm SD & $167.5 \pm 48.054$ & $253.5 \pm 73.414$ & \\
\hline
\end{tabular}

Table (6): Side effects of the two study groups.

\begin{tabular}{lcc}
\hline & $\begin{array}{c}\text { Misoprostol } \\
(\mathrm{n}=26)(\%)\end{array}$ & $\begin{array}{c}\text { IMN } \\
(\mathrm{n}=29)(\%)\end{array}$ \\
\hline Symptom free & $11(42)$ & $18(62)$ \\
Abdominal pain & $11(42)$ & $1(3)$ \\
Headache & 0 & $10(35)$ \\
Palpitation & 0 & 0 \\
Vaginal bleeding & $2(8)$ & 0 \\
Nausea/vomiting & $2(8)$ & 0 \\
Diarrhea & 0 & 0 \\
Dizziness & 0 & 0 \\
\hline
\end{tabular}


There was a significant difference between the two groups (Misotac \& IMN) regarding the intraoperative blood loss $(p$-value $=0.0004 *)$.

On comparing the noticeable side effects of the two drugs, it was clear that the nitric oxide donor (IMN) "group II" had much less side effects where almost $62 \%$ were symptom-free against only $42 \%$ for the misoprostol (Misotac) "group I". As for other side effects (e.g. abdominal pain, headache $\&$ vaginal bleeding) varied as shown in (Table 6).

\section{Discussion}

Missed abortion is defined as unrecognized intrauterine death of the embryo or fetus without expulsion of the products of conception [1]

Expectant management has been reported with unpredictable success rate ranging from $25-76 \%$. Waiting for spontaneous expulsion of the products of conception would waste much time, during which women may suffer uncertainty and anxiety [2]. Moreover surgical evacuation could be needed owing to failure, so intervention is better either medical or surgical. Traditionally, the first trimester miscarriage, is terminated by surgical evacuation of the uterus [3,4]. Although, this procedure was introduced to reduce the risk of infection and hemorrhage, it is reported to be associated with many complications including cervical trauma, perforation of the uterus, endometritis and cervical incompetence [5].

Prostaglandin-E1 agonist misoprostol is well established in labor induction at term, termination of second trimester pregnancies and cervical ripening before first trimester curettage [6]

Isosorbide mononitrate is a nitric oxide donor and vasodilator used primarily for patients with angina pectoris [7]. The discovery that the expression of inducible nitric oxide synthase isoforms in the human cervix increases toward the end of pregnancy suggested a potential therapeutic role for nitric oxide donors in the cervical ripening process [8].

The objective of our study is to minimize the incidence of surgical complications owing to performing surgical abortion, in cases of early missed abortion with unripe cervix e.g. false track, cervical trauma or uterine perforation, by comparing the effect of Isosorbide Mononitrate (IMN) and Misoprostol in ripening the cervix in these cases for any likely indication favoring the surgical over the medical management.
In our study, vaginal application of vaginal tablets of $80 \mathrm{mg}$ isosorbide mononitrate and $400 \mathrm{gg}$ misoprostol were equally effective in cervical priming prior to surgical abortion but in terms of operative blood loss and induction-to-ripening interval misoprostol was found to be better than isosorbide mononitrate.

Uzma Shafique, Farzana Kazmi, Farah Rehana [9] stated that: Both the drugs were used until the ripening, the frequency of doses was relatively higher in IMN group and the induction-ripening interval was comparatively higher in IMN group than the misoprostol group. These finding was consistent with our study where the no. of doses given to achieve the required level of ripeness in this study was about 3 doses and the no. of IMN doses was about 5 doses.

In our study misoprostol was found to be more effective cervical ripening agent than IMN as the results showed that patients received misoprostol took much less induction interval time and less amount of blood loss than those received IMN prior surgical evacuation by vacuum aspiration as shown in (Table 4) almost about $92 \%$ of group (I) was ripened cervix compared to only $48 \%$ of group (II) after the fourth dose (first 24 hours of initiating the ripening process); similar results and conclusion were seen in Marie-Anne Ledingham et al., [10] who found that misoprostol is a more effective cervical ripening agent in the first trimester than the nitric oxide donor isosorbide mononitrate.

In terms of blood loss and safety of cervical ripening agents our study found that misoprostol has high efficacy and safety of misoprostol in cases of missed miscarriage unlike IMN where amount of blood loss in group (I) ranged between (100$250 \mathrm{ml})$ and in group (II) was (150-350ml) exhibiting much statistical significance ( $p$-value 0.0004); this was consistent with Shahida Tasneem, Muhammad Gul, Kinza Alam et al., conducted the study on seventy women of missed miscarriage recruited found that misoprostol had high efficacy and safety in cases of missed miscarriage. Hemoglobin $(\mathrm{Hb})$ was checked on ${ }^{\mathrm{st}}$ and 8 th day. Patients who had fall in $\mathrm{Hb}$ of more than $2 \mathrm{gm}$ from baseline were labeled as group in which drug was unsafe. Safety of misoprostol was established in $87.1 \%$. However for $12.9 \%$ was unsafe [11].

Also Amatunnafe Naseha, Mohammed Ismail Khan deducted that NO donors like IMN are relatively a safe option for use as cervical ripening agent as a pre-treatment for surgical evacuation of retained products of conception, which disagreed 
with our study, with more privilege of misoprostol for its definite beneficial effect of misoprostol over IMN in reduction of blood loss during procedure. They found that, though IMN is a potential cervical ripening agent, Misoprostol appears to be more effective and faster in causing cervical ripening

Other adverse effects noted e.g. nausea, vomiting, hypotension and tachycardia but there were no significant difference between both groups which agrees with results obtained by Ivy L, et al.,

In our study IMN showed less side effects than the misoprostol group giving that about $62 \%$ were symptom-free compared to only $42 \%$ of the misoprostol group and there was a significant difference between the two groups in regards of abdominal pain as a side effect where $42 \%$ of the Misoprostol group complained from abdominal pain where only $3 \%$ of the IMN group gave this complaint.

These results were confirmed by similar results obtained by Amatunnafe Naseha, Mohammed Ismail Khan [12] that showed abdominal pain as a main side effect of misoprostol and headache as main side effect of IMN.

This may be due to the proved fact that Misoprostollead to development of uterine contractions this in agreement with Chanrachakul B., et al. [14], Shrikant B., et al., [15], Lauric B., et al., [16], Waleed El-Khayat et al., [17], the latter stated that there was a significant difference between IMN and misoprostol as regard to abdominal pain, his results showed (17 cases for IMN and 55 cases for misoprostol) [17].

In contrast, no inhibits myometrial contractions of the pregnant corpus uteri while inducing cervical ripening. The IMN relax the myometrium while inducing cervical ripening and this in agreement with Chanrachakul B., et al., [14], Filomena P., et al., [18], as Chanrachakul [14] found that none of the patients treated with IMN for inducing cervical ripening at term had developed any side effects that developed with the use of misoprostol especially uterine hypertonicity and abdominal pain. On the other hand; the side effects after initiation of cervical ripening were similar between the two groups with regard to nausea, diarrhea, flushing, palpitations, and dizziness. Headache, however, was reported by nearly $35 \%$ of women who received isosorbide mononitrate compared with no cases $0 \%$ who received misoprostol. This finding was similar to what Dave Anupama et al., [19] concluded, regarding the main side effect was headache which was experienced by 30 cases (20\%), but nearly all of them had mild headache which was tolerable. This result is lower than what Osman et al., [20] reported. Ekerhovd et al., also reported headache in 24 cases from $30(80 \%)$ [21]

In the end we faced in this study some difficulties including patients noncompliance, some refused to continue the trial, certain side effects especially abdominal pain and headache are subjective data with great personal variability and tolerability and more importantly that group of patients experienced successful medical abortion. The success rate of medical abortion with misoprostol in case of missed miscarriage in Shahida et al., study [17] was $68.6 \%$ which is comparable to some studies. However, success rate was markedly low as compared to $84.1 \%$ by Wagaraachchi et al., [22] and $77.3 \%$ by Shankar et al., [23] in comparison with our study which showed marked decline in success rate of medical evacuation $(25 \%)$ which may be attributed to small number of our recruited cases. Abdominal pain and headache were manageable with simple analgesia e.g. paracetamol.

\section{Conclusion:}

Misoprostol is a better cervical ripening agent with quicker response, less side effects, better acceptability, leading to early surgical evacuation and short hospital stay than isosorbide mononitrate prior to suction evacuation of first trimester missed abortion.

\section{Acknowledgments:}

This research was carried out without funding.

\section{Conflicts of interest:}

No conflicts of interest declared.

\section{Authors' contributions:}

All authors had equal role in design, work, statistical analysis and manuscript writing. All authors have approved the final article work.

\section{References}

1- WOOD S.L. and BRIAN P.H.: Medical management of missed abortion: A randomized clinical trial. Obstet. Gynecol., 99: 563-6, 2002.

2- LUISE C.: Outcome of expectant management of spontaneous first trimester miscarriage: Observational study. BMJ, 324: 873-5, 2002.

3- SHANKAR M., ECONOMIDES D.L., SABIN C.A., TAN B. and KADIR A.: Outpatient medical management of missed miscarriage using misoprostol. J. Obstet. Gynaecol., 27 (3): 283-6, 2007.

4- COUGHLIN L.B., ROBERTS D., HADDAD N.G. and LONG A.: Medical management of first trimester miscar- 
riage (blighted ovum and missed abortion): Is it effective? J. Obstet. Gynaecol., 24 (1): 69-77, 2004.

5- EL-SAYED M.M., MOHAMMED S.A. and JONES M.H.: Expectant management of first-trimester miscarriage. J. Obstet. Gynaecol., 29 (8): 681-5, 2009.

6- ELSHEIKH A., ANTSAKLIS A., MESOGITIS S., PAPANTONIOU N., RODOLAKIS A. and VOGAS E. MICHALAS S.: Use of misoprostol for the termination of second trimester pregnancies. Arch. Gynecol. Obstet., 265: 204-6, 2001.

7- GUNASEKARA N.S. and NOBLE S.: Isosorbide 5mononitrate: A review of a sustained-release formulation (Imdur) in stable angina pectoris. Drugs, 57: 261-77, 1999.

8- TSCHUGGUEL W., SCHNEEBERGER C., LASS H., STONEK F., ZAGHLULA M.B., CZERWENKA K., et al.: Human cervical ripening is associated with an increase in cervical inducible nitric oxide synthase expression. Biol. Reprod, 60: 1367-72, 1999.

9- UZMA SHAFIQUE, FARZANA KAZMI and FARAH REHANA: Vaginal Isosorbide Mononitrate and Misoprostol for Induction of Cervical Ripening Prior to 1 st Trimester Surgical Evacuation of Retained Products of Conception. Journal of Rawalpindi Medical College (JRMC), 14 (2): 101-3, 2010.

10-MARIE-ANNE LEDINGHAM, ANDREW J. THOMSON, C. BURNETT LUNAN, IAN A. GREER and JANE E. NORMAN: A comparison of isosorbide mononitrate, misoprostol and combination therapy for first trimester pre-operative cervical ripening: A randomised controlled trial. British Journal of Obstetrics and Gynaecology March, 108: 276-80, 2001.

11- SHAHIDA TASNEEM, MUHAMMAD SARFRAZ GUL, SARWAT NAVID and KINZA ALAM: Efficacy and safety of misoprostol in easly miscarriage in terms of blood loss. Rawal. Med. J., 39: 314-8, 2014.

12- AMATUNNAFE NASEHA and MOHAMMED ISMAIL KHAN: A comparative assessment of misoprostol and isosorbide mononitrate as cervical ripening agents for surgical evacuation in first trimester missed miscarriages: A randomised controlled trial: International Journal of Medical Science and Clinical Inventions, 4 (5): $2894-$ 900, 2017.

13- CUNNIGHAM G.H., GANT N.F. and LEVENO K.J. Inadequate labour. In Cunnigham FG, Williams J.W.: Willims Obstetrics, 21 th edition. New York, 432-43, 2001.

14- CHANRACHAKUL B., HERABUTYA Y. and PUNYA-
VACHIRA P.: Randomized trail of isosorbide mononitrate versus misoprostol for cervical ripening at term. Int. J. Obs./Gyn., 78 (2): 139-45, 2002.

15- SHRIKANT B., FIONA M. JOHN N., STAVROS P., MARGARET R., IAN G. INASS O. and JANE E. NORMAN: Randomised placebo trail of out patient cervical ripening with IMN prior to induction of labour. Clinical trail with analysis of efficacy, cost effective and acceptability BMC pregnancy and child birth, (25): 25, 2006.

16- LAURIE B. and CHARLES V.: Controlled-Release misoprostol vaginal inserts effectively induce labour. Medscape medical news, 31 Oct., 2007.

17- WALEED EL-KHAYAT, AHMED MAGED and HASSAN OMAR: Acomparative study between isosorbide mononitrate (IMN) versus misoprostol prior to hysteroscopy. Middle East Fertility Society Journal, 15: 278-80, 2010.

18- FILOMENA P. NUNES, ANA P. CAMPOS, SONIA R. PEDDROSO, CRISTINA F. LEITE, TERESA $P$. AVILLEZ, ROSALINDA D. RODRINGUES and MANUEL M.: Intravaginal glyceryl trinitrate and dinoprostone for cervical ripening and induction of labour. American Journal of Obs./Gyn. April, 194 (4): 1022-6, 2006.

19- DAVE ANUPAMA, NIGAM PRIYANKA and MARU LAXMI: Isosorbide Mononitrate a Nitric Oxide Donor: A Study of Its Efficacy and Safety as an Agent for Cervical Ripening. The Journal of Obstetrics and Gynecology of India (May-June), 65 (3): 162-6, 2015.

20- OSMAN I., MacKENZIE F., NORRIE J., et al.: The "PRIM" study: A randomized comparison of prostaglandin E2 gel with the nitric oxide donor isosorbide mononitrate for cervical ripening before the induction of labor at term. American Journal of Obstetrics and Gynecology Apr., 194 (4): 1012-21, 2006.

21- EKERHOVD E., BULLARBO M., ANDERSCH B., et al.: Vaginal administration of the NO donor IMN for cervical ripening at term: A randomized controlled study. Am. J. Obstet. Gynecol., Dec., 189 (6): 1692-7, 2003.

22- PATUA B.: An approach to evaluate the efficacy of vaginal misoprostol administration for a rapid management of first trimester spontaneous onset incomplete abortion, in comparison to surgical curettage. Arch. Gyne. Obst., 288: 1243-8, 2013.

23- PANG M.W., LEE T.S. and CHUNG T.K.: Incomplete miscarriage: A randomized control trial comparing oral with vaginal misoprostol for medical evacuation. Hum. reprod., 16: 223-7, 2001. 


\section{دراسة مقارثة تآثير إيزوسورييد موثونيترات مقابل الميزوبروستول

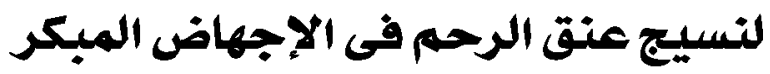

نضج عنق الرحم يعنى ترقت وتنعيم وفتح عنق الرحم. مختف الطرق الدوائية والغير دوائية متاحة لإنضاج عنق الرحم الرئ لكل منها مزاياها

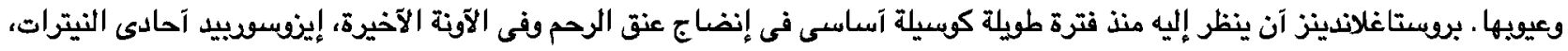

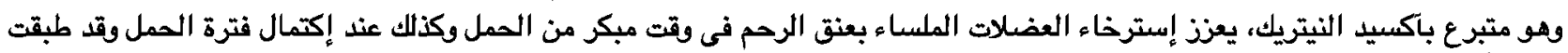

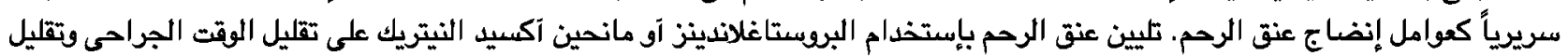
فقدان الدم ويجعل التوسيع الميكانيكى آسهل.

هدف الدراسة: مقارنة فعالية إيزوسوبيد آحادى النيترات والميزوبروستول لتدقيق آفضل نضجج لعنق الرحم قبل الإجهاض الجراحى فى الإسى الثلث الأول للإجهاض المبكر المفقود.

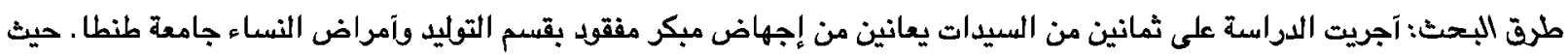

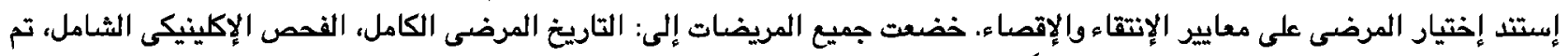
عمل سونار مهبلى ثم تم مقارنة النتائج إحصائياً.

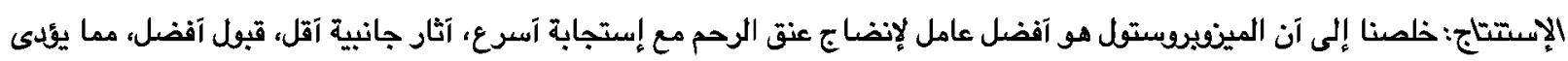

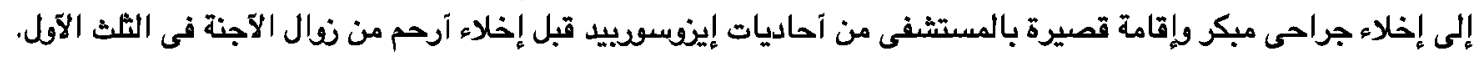

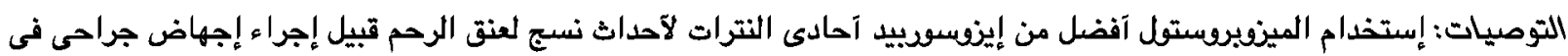

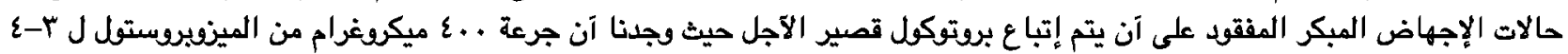

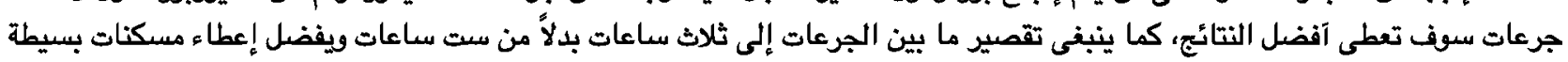

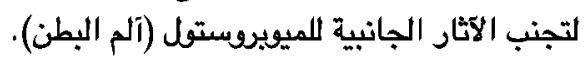
مزيد من التجارب ممكن إجراؤها لتحديد ما إذا كان سيوجد مزايا آو آثار جانبية إضافية جراء إستخدام العقارين مجتمعين لآحداث نسج آفضل لعنق الرحم. 